\title{
Co-infectivity of hepatitis B virus and hepatitis E virus
}

\author{
Akanksha Singh", Shiwani Singh, M Ahmad Ansari, M Irshad \\ From First International Science Symposium on HIV and Infectious Diseases (HIV SCIENCE 2012) \\ Chennai, India. 20-22 January 2012
}

\section{Background}

Viral hepatitis is a major health problem and is an important cause of morbidity and mortality throughout the world. Present study is aimed to assess the co-infection of hepatitis $E$ virus with hepatitis B virus in HBVDNA positive cases.

\section{Methods}

A total number of 40 adult patients from various liver diseases with high level of ALT and AST were included in this study and were analyzed for hepatitis viral marker including HBsAg and IgM anti-HEV. The detection of HEV-RNA in $32 \mathrm{HBV}$-DNA positive cases was done by Real Time PCR.

\section{Results}

The results of this study demonstrate that hepatitis $\mathrm{E}$ virus (HEV-RNA) infection to be rare (6.25\%) in HBVDNA positive cases. Surface antigen (HBsAg) for hepatitis B virus was positive in 18 cases $(45 \%)$ and IgM Anti HEV was positive in 16 cases (40\%). Hepatitis B virus infections, as the predominant causes of liver diseases, HBV-DNA was detected in 32 cases out of 40 cases and HEV-RNA was detected in 2 cases out of 32 HBV-DNA positive cases respectively. Co-infection of both HBV and HEV were reported in acute and chronic liver diseases in more than $18 \%$ cases by ELISA and $6.25 \%$ cases by real time PCR.

\section{Conclusion}

HBV and HEV are the major cause of acute and chronic liver diseases. The data from this study indicates that presence of HEV-RNA in HBV-DNA positive cases, is

\footnotetext{
* Correspondence: akanksha.aks06@gmail.com

Dept. of Laboratory Medicine, All India Institute of Medical Sciences, Ansari Nagar, New Delhi-29, India
}

(c) 2012 Singh et al; licensee BioMed Central Ltd. This is an Open Access article distributed under the terms of the Creative Commons Attribution License (http://creativecommons.org/licenses/by/2.0), which permits unrestricted use, distribution, and reproduction in any medium, provided the original work is properly cited. rare in population. The co-infection of hepatitis B virus

Published: 4 May 2012

doi:10.1186/1471-2334-12-S1-P1

Cite this article as: Singh et al:: Co-infectivity of hepatitis B virus and hepatitis E virus. BMC Infectious Diseases 2012 12(Suppl 1):P1. and take full advantage of:

- Convenient online submission

- Thorough peer review

- No space constraints or color figure charges

- Immediate publication on acceptance

- Inclusion in PubMed, CAS, Scopus and Google Scholar

- Research which is freely available for redistribution

Submit your manuscript at 